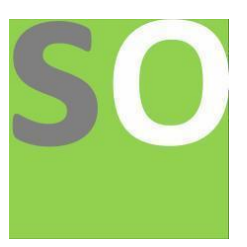

Article title: The Cooperative Integrated Reading And Composition (CIRC) Strategy In Teaching Reading Comprehension Teaching Comprehension

Authors: Andi Asrifan[1], Like Raskova Octaberlina[2]

Affiliations: Universitas Muhammadiyah Sidenreng Rappang, Indonesia[1], Universitas Islam Negeri Maulana Malik Ibrahim, Malang, Indonesia[2]

Orcid ids: 0000-0002-9934-6129[1]

Contact e-mail: andiasrifan@gmail.com

License information: This work has been published open access under Creative Commons Attribution License http://creativecommons.org/licenses/by/4.0/, which permits unrestricted use, distribution, and reproduction in any medium, provided the original work is properly cited. Conditions, terms of use and publishing policy can be found at https://www.scienceopen.com/.

Preprint statement: This article is a preprint and has not been peer-reviewed, under consideration and submitted to ScienceOpen Preprints for open peer review.

DOI: 10.14293/S2199-1006.1.SOR-.PPMY3FC.v1

Preprint first posted online: 11 January 2021

Keywords: Cooperative Integrated Reading and Composition, Reading Comprehension, Narrative Text 


\title{
THE COOPERATIVE INTEGRATED READING AND COMPOSITION (CIRC) STRATEGY IN TEACHING READING COMPREHENSION
}

\author{
${ }^{1}$ Andi Asrifan, ${ }^{2}$ Like Raskova Octaberlina, ${ }^{3}$ Anriani Ali \\ 1,3Universitas Muhammadiyah Sidenreng Rappang \\ ${ }^{2}$ Universitas Islam Negeri Maulana Malik Ibrahim, Malang, Indonesia
}

\begin{abstract}
The objective of this research was : to find out whether or not a cooperative integrated reading composition strayegy can improve the reading comprehension of Eighth grade of students at SMP Negeri 2 Baranti.This research apply pre-experimental design with one group pre-test and post-test. The population of this research was four classes at SMP Negeri 2 Baranti in academic year 2019/2020 with the total population were 120 students. The sample of this research were VIII.A (30 students). This sample was taken by cluster sampling technique. This research applied reading test to know the students' reading comprehension through cooperative integrated reading and composition strategy. The researcher found that by using cooperative integrated reading and composition in teaching reading comprehension, it could improved the reading comprehend of the eighth grade students of SMP Negeri 2 Baranti. It was proved by $p$-value of post-test was lower than the $\alpha(0,000<0,05)$. So, the researcher stated that $\mathrm{H}_{0}$ was rejected and $\mathrm{H}_{1}$ was accepted. Based on the data analysis, the researcher concluded that: Cooperative integrated reading and composition strategy could improved students' reading comprehension.
\end{abstract}

Key words : Cooperative Integrated Reading and Composition, Reading Comprehension and Narrative Text

\section{INTRODUCTION}

Rosenblatt in Moreillon (2007) stated that reading as a transaction between the reader, the text, and the intention of the author. He suggests that each reader brings his own feelings, personality, and experience to the text and that each reader was different each time he visits certain texts. In addition Moreillon (2007) stated that reading was making meaning from print and from visual information. But reading was not simple. Reading was an active process that requires a lot of practice and skills. There are several types of reading, that was intensive reading, extensive reading, aloud reading and silent reading. In this study, the researcher focused on reading comprehension. Reading comprehension was in the intensive reading section. Woolley (2011) stated that “... reading comprehension is enhanced when visual and verbal information are linked in the working memory. In addition, it is stated that the quality of the reader's mental representation can be improved when readers are encouraged to visualize story content and enter into dialogue (in one-to-one or group teaching settings)". In addition Wolley (2011) stated that reading comprehension is 
the process of making meaning from text. Therefore, the aim is to obtain a thorough understanding of what is explained in the text rather than to get meaning from isolated words or sentences.

In reading learning, the problem that is often experienced by students is that students can not understand the reading text to find the main ideas and answer questions related to the reading text. Therefore, an appropriate, effective and interesting learning strategy is needed so that reading learning becomes more enjoyable and works well.

From the point of problems faced by the subject under study, good reading teaching strategy must be able to stimulate high motivation, interest and attention of students. In other words, good strategy can motivate and promote students to understand the text in reading activities in the classroom. One way to improve reading comprehension of the students was by using cooperative integrated reading and composition strategy in teaching reading comprehension.

\section{REVIEW OF RELATED LITERATURE}

\section{The Concept of Reading}

To begin with, Just and Carpenter in Wolley (2011) stated that reading was an active process in which the reader interacts with the text and constructs meaning, for example, in understanding foreign words by relating them to the scheme and background of existing knowledge. Secondly Woolley (2011) stated that reading inherently about language. To understand why some students do not progress by reading as they should, one must understand the role of language in determining the success of long-term reading. Moreover, Mubarok and Sofiana (2017) stated that reading is an activity to comprehend written text in order to get information, knowledge, and messages implicitly or explicitly.

\section{The Concept of Cooperative Integrated Reading and Composition}

Steven and Slavin in Mayuni (2000) stated that CIRC is a technique in which students work on their team in various cooperative activities including reading couples, identifying key story elements, vocabulary and summarization activities, reading comprehension strategy practices, and creative writing using the process of writing approach. Group work is believed can improve student motivation. Cooperative Integrated Reading and Composition learning steps. According to Kessler in Ristanto et,al (2018) the learning steps are as follows: (1) Students are grouped into several heterogeneous groups, (2) Each group reads an article or a reading, (3) Students rewrite the result of discussion on a worksheet, (4) Each group displays or presents their results, (5) The best group is rewarded.

\section{Objective of The Study}

The objective of this study, the researcher was to find out whether or not a cooperative integrated reading composition strategy can improve the reading comprehension of Eighth grade of students at SMP Negeri 2 Baranti.

\section{METHOD}

\section{A. Research Design}


In this research, the research applied pre-experimental design with one group pre-test, treatment and post-test to know the students' ability in reading. The group test was given pre-test and post-test in which the pre-test was administered to measure prior competence of reading while the post-test was administered to measure the effect of the treatment. The design was presented in the following :

\begin{tabular}{llll}
\hline Group & Pre-Test & Treatment & Post-test \\
\hline $\mathrm{N}$ & $\mathrm{O}_{1}$ & $\mathrm{X}$ & $\mathrm{O}_{2}$ \\
\hline
\end{tabular}

\section{B. Variables of the Research and Operational Definition of Variable}

1. Variable of The Research

There were two variable in this research namely independent variable $(X)$ and dependent variable $(Y)$. The independent variable was the use of cooperative integrated reading and comprehension strategy and the dependent variable was the students' achievement in reading comprehension (X). The paradigm design of the variable is reveale in figure below :

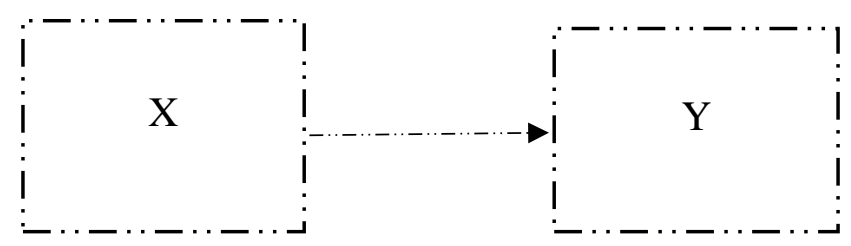

Sugiyono (2014)

2. Operational Definition of Variable

To make clear the variables in this research, the researcher describes the operational definition as follow :

a. Reading comprehension was the ability to process text, understand its meaning, and combine it with what the reader already knows.

b. Cooperative integrated reading and composition was strategy to measure students' response of the text by making conclusion based on the text.

\section{Population and Sample}

The population of this research is the Eighth grade students of SMP Negeri 2 Baranti, in academic years 2019/2020.

\begin{tabular}{cc}
\hline No. & Total Students \\
\hline Class VIII.A & 30 \\
Class VIII.B & 30 \\
Class VIII.C & 30 \\
Class VIII.D & 30 \\
Total Number & 120 \\
\hline
\end{tabular}

There are many types of technique sampling. In this research, the research applied cluster sampling technique. The researcher using cluster sampling technique because according to researchers the source of data in the school to be studied was a vast source, and the population that has been determined by the researcher is eighth grade, so the sample studied is class VIII.A. The number of total sample is 30 students. 


\section{Instrument of the Research}

To collected the data, the researcher is utilized a reading test as the instrument, where consists of 30 questions, they were multiple choices, true or false and fill in the blanks test. The test was applied for pre-test and post-test. The post-test aim to finding out the prior reading achievement of the students, while post-test aim at finding out the students' reading comprehension skill after treatment was given (teaching with reading comprehension through cooperative integrated reading and composition in reading was a strategy to measure students' achievement in reading comprehension).

\section{E. Procedure of Collecting Data}

The procedure of the research involved the following steps :

1. Pre-test conducting treatment at the first meeting the following procedures :

a. The researcher explained what the students were going to do and distribute the reading comprehension test for the class, to know the students' reading comprehension before treatment,

b. The researcher gives score to the students' result test.

2. Post-test

a. After gave the treatment, the students are give a set of reading comprehension test,

The reseracher gave score of the students' result test.

\section{RESULTS}

1. The rate percentage score of pre-test and post-test in reading comprehension

\begin{tabular}{ccccccc}
\hline NO & Classification & Score & \multicolumn{2}{c}{ Pre-Test } & \multicolumn{2}{c}{ Post-test } \\
\cline { 3 - 6 } & & $\mathrm{F}$ & $(\%)$ & $\mathrm{F}$ & $(\%)$ \\
\hline 1 & Very Good & $86-100$ & 0 & 0 & 0 & 0 \\
2 & Good & $71-85$ & 0 & 0 & 6 & 20 \\
3 & Fair & $56-70$ & 0 & 0 & 19 & 63 \\
4 & Poor & $41-55$ & 5 & 17 & 5 & 17 \\
5 & Very Poor & $<40$ & 25 & 83 & 0 & 0 \\
\hline & TOTAL & & 30 & 100 & 30 & 100 \\
\hline
\end{tabular}

Based on the table above, it explaines that the students in the pre-test got very poor and poor classifications, 25 (83\%) students categorize in very poor, $5(17 \%)$ students categorize in poor but in the post-test most of them get fair classification, $19(63 \%), 5$ $(17 \%)$ get poor classifications and $6(20 \%)$ get good classifications. It is concluded that in the post-test the researcher had see an increasing although there was nineteen students get fair classification in post-test. In the indicated that the students achievement increased after being taught using cooperative integrated reading and composition straregies.

2. The mean score and standard deviation of the students pre-test and post-test

\begin{tabular}{cccc}
\hline No. & Variable & Mean score & Standard deviation \\
\hline 1. & Pre-test & 30,43 & 10,348
\end{tabular}


From the table shows that the mean score of the students in post-test $(63,20)$ was greater than pre-test $(30,43)$, it means that the students who was thaugh by using cooperative integrated reading and composition strategy was improved.

3. The p-value of the students' score.

\begin{tabular}{cc}
\hline$\alpha$ & $p$-value \\
\hline 0.05 & 0.000 \\
\hline
\end{tabular}

Based on the table above, shows that $\alpha$ was higher than $p$ value, it means null hypothesis $\left(\mathrm{H}_{0}\right)$ was rejected and alternative hypothesis $\left(\mathrm{H}_{1}\right)$ was accepted. It meant that the eighth grade students of SMP Negeri 2 Baranti after applied of CIRC strategies in students reading comprehension was improved.

\section{Conslusion}

Based on the finding and discussion in the preceding chapter, it could be concluded that teaching reading comprehension in English through Cooperative Integrated Reading and Composition strategy at the Eighth grade students of SMP Negeri 2 Baranti was improved. It was proved by $p$-value was lower than the $\alpha(0,000<0,05)$, and the mean score of pre-test lower than post test $(30,43<63,20)$. These means that the use of Cooperative Integrated Reading and Composition strategy can improved students' reading comprehension.

\section{Suggestion}

On the basic of result, some suggestions were presented in an effort to improve the students' reading comprehension :

1. The English teachers are suggested to use other technique in order teaching material subject, especially in teaching reading in narrative text.

2. The students are suggested to apply cooperative integated reading and composition strategy as guidance to increase their comprehend in reading and motive them in learning English better.

3. The next researchers are suggested to continue this research in the future, and it is suggested to other researcher to carry out to further studies about the use of cooperative integrated reading and composition strategy to another teaching and another strategy in increasing students'reading comprehension.

4. The teachers should give more chance to the students to be more active and let them to do some practices in reading and they should apply the various teaching strategy and learning strategies in teaching reading in order to make the students easy to improve their reading comprehension. One of te various teaching which were able to improve the reading comprehension through cooperative integrated reading and composition strategy.

\section{BIBLIOGRAPHY}


Gay, L.R., et al. 2006. Educational Research Competence for Analysis and Applications: Eighth Edition. Columbus Ohio. Pearson Merril Prentive Hall.

Mayuni, Luh Rai. 2014. Teaching Reading Comprehension Through Cooperative Integrated Reading and Composition (CIRC) to the Eighth Grade Students of SMPN 3 Sukawati in Academic Year 2013/2014. Thesis. Denpasar: Maharaswati Denpasar University.

Moreillon. 2009. Collaborative Strategies for Teaching Reading Comprehension. Chicago: American Library Association.

Mubarok, $\mathrm{H}$ and Sofiana,N. 2017. Cooperative Integrated Reading and Composition (CIRC) and Reading Motivation : Examining The Effect On Students' Reading Abliity. Lingua Cultura. https://www.researchgate.net

Ristanto, et.al. 2018. The Potential of Cooperative Integrated Reading and Composition in Biology Learning at Higher Education. International Journal of Educational Research Review. Volume 3, Januari 2018. https://www.ijere.com.

Wolley. 2011. Reading Comprehension : Assisting Children with Learning Difficulties. New York : Springe Dordrecht Heidelberg. http://www.mainlesson.com/display.php?author=raju\&book=fables\&story=tortoise. diakses pada 20 oktober 2018 (Online)

Asrifan, A. (2009). Using songs in teaching English language for the young learners. ParePare: unpublished.

Puasa, K., Asrifan, A., \& Chen, Y. (2017). Classroom Talk in Bilingual Class Interaction. Research in Pedagogy, 7(1), 106-121.

Nadirah, N., Tahir, M. H., \& Asrifan, A. (2019). THE ABILITY TO TRANSLATE ENGLISH PHRASES INTO INDONESIAN AND THE DIFFICULTIES FACED BY THE ELEVENTH GRADE STUDENTS OF SMAN 1 PANCARIJANG. JOURNAL OF ADVANCED ENGLISH STUDIES, 2(1), 41-46.

Apdy, A. P. R., \& Asrifan, A. (2019, April). The Chinese mime game in teaching vocabulary on EFL classroom. In PROCEEDINGS OF THE 65th TEFLIN INTERNATIONAL CONFERENCE (Vol. 65, No. 01).

Taslim, T., Asrifan, A., Chen, Y., \& Nurdania, N. R. (2019). CORRELATION BETWEEN STUDENT'S VOCABULARY MASTERY AND SPEAKING SKILL. JOURNAL OF ADVANCED ENGLISH STUDIES, 2(2), 65-76.

Muthmainnah, M., Asrifan, A., Al Yakin, A., \& Sahabuddin, C. (2019, April). The use of dictogloss technique on ELT classroom: An experiment study of students listening comprehension. In PROCEEDINGS OF THE 65th TEFLIN INTERNATIONAL CONFERENCE (Vol. 65, No. 01).

Mutmainnah, M., Azis, S., Maulidya, U., \& Asrifan, A. (2017). Glory Style in Mandar Song Lyrics: A study of Mandar Tribe in South Sulawesi, Indonesia. JOURNAL OF ADVANCES IN LINGUISTICS, 8(1), 1286-1291.

Asrifan, A., Rinantanti, Y., Tang, S., \& Nadirah, N. (2019). THE 3-DIMENSION PICTURES IN INCREASING THE STUDENTS ABILITY AND INTEREST TO WRITE DESCRIPTIVE COMPOSITION. JOURNAL OF ADVANCED ENGLISH STUDIES, 2(1), 19-30.

Asrifan, A., Nadira, N., \& Haedar, H. (2018). IMPROVING STUDENTS'READING COMPREHENSION OF DESCRIPTIVE TEXT THROUGH COLLABORATIVE MURDER. JOURNAL OF ADVANCED ENGLISH STUDIES, 1(2), 21-31.

Asrifan, A. (2015). Analysis of English Students' Learning Style in Bilingual Class. International Journal of Literature and Arts, 3(4), 34. 
Farahdiba, S., \& Asrifan, A. (2016). Speaking Ability and Psychological Barriers of the Second Year Students of Hotel Department of SMKN 1 Sidenreng Kabupaten Sidrap in Speaking English. Asian EFL Journal, (89), 41.

Asrifan, A. (2012). Increasing the Students Ability to Write Descriptive Composition at SMP Negeri 13 Parepare by using the 3-Dimension Pictures.

Tang, S., Asrifan, A., Chen, Y., Haedar, H., \& Agussalim, M. (2019). THE HUMOR STORY IN TEACHING READING COMPREHENSION. JOURNAL OF ADVANCED ENGLISH STUDIES, 2(2), 77-87.

Nurwanti, N., Asrifan, A., \& Haedar, H. (2019). THE APPLICATION OF COOPERATIVE LEARNING: JIGSAW II TECHNIQUE IN IMPROVING STUDENTS'READING COMPREHENSION OF EXPOSITORY TEXT. JOURNAL OF ADVANCED ENGLISH STUDIES, 2(1), 31-40.

Asrifan, A. (2016). The Effectiveness of Think-Pair-Share Technique in Improving Studentsâ $€^{\mathrm{TM}}$ Speaking Ability and Interest. English Literature and Language Review, 2(3), 24-35.

Asrifan, A., Muthmainnah, M., Al-Yakin, A., Sahabuddin, C., \& Haedar, H. (2018). THE CAUSE-EFFECT TECHNIQUE IN TEACHING RECOUNT WRITING. JOURNAL OF ADVANCED ENGLISH STUDIES, 1(2), 63-72.

Asrifan, A., Vargheese, K. J., Syamsu, T., \& Amir, M. (2020). ESP COURSE DESIGN: THE NEED ANALYSIS ON TOURISM DEPARTMENT IN INDONESIA VOCATIONAL HIGH SCHOOLS. JOURNAL OF ADVANCED ENGLISH STUDIES, 3(2), 69-77.

Asrifan, A., Ghofur, A., \& Azizah, N. (2020). Cheating Behavior in EFL Classroom (A Case Study at Elementary School in Sidenreng Rappang Regency). OKARA: Jurnal Bahasa dan Sastra, 14(2), 279-297.

Nadirah, N., Asrifan, A., Vargheese, K. J., \& Haedar, H. (2020). INTERACTIVE MULTIMEDIA IN EFL CLASSROOM: A STUDY OF TEACHING READING COMPREHENSION AT JUNIOR HIGH SCHOOL IN INDONESIA. JOURNAL OF ADVANCED ENGLISH STUDIES, 3(2), 131-145.

Muthmainnah, A. R., Atmowardoyo, H., Salija, K., \& Asrifan, A. (2020). Literary Work as Teaching Materials: A Study of Students and Lecturers Needs Analysis. Solid State Technology, 63(5), 394-407.

Tilome, A. A., Agustang, A., Jasruddin, M. S., \& Asrifan, A. (2020). Social Exchange of Political Elites in the Regional Leader Election of Gorontalo Province, Indonesia. Solid State Technology, 63(5), 521-531.

Pacinongi, A., \& Asrifan, A. (2020). Bimbingan Pengawas Berkelanjutan dalam Mewujudkan Pendidikan Karakter Bangsa dalam Kegiatan Belajar Mengajar Penjaskes. Celebes Education Review, 2(1), 1-7.

Gunawan, G., \& Asrifan, A. (2020). Penerapan Kerja Kelompok Kegiatan MGMP Guru Ekonomi dalam Menyusun RPP untuk Meningkatkan Kompetensi Pedagogik. Celebes Education Review, 2(1), 31-36.

Yusuf, I., \& Asrifan, A. PENINGKATAN AKTIVITAS KOLABORASI PEMBELAJARAN FISIKA MELALUI PENDEKATAN STEM DENGAN PURWARUPA PADA SISWA KELAS XI IPA SMAN 5 YOGYAKARTA. Editorial Team, 32.

Al Yakin, A., Sahabuddin, C., Rahayu, A., Fitrah, N., \& Arifin, M. (2020). Political Celebrification and Electability: A Study of Political Phenomena Imaging in Election Polewali Mandar District, West Sulawesi, Indonesia. Solid State Technology, 63(5), 632-646. 
Junaedah, S. B. T., \& Ahmad, M. A. (2020). The Outdoor Learning Modules Based on Traditional Games in Improving Prosocial Behaviour of Early Childhood. International Education Studies, 13(10).

Octaberlina, L. R., \& Muslimin, A. I. (2020). Efl students perspective towards online learning barriers and alternatives using moodle/google classroom during covid-19 pandemic. International Journal of Higher Education, 9(6), 1-9.

Octaberlina, L. R., \& Anggarini, I. F. (2020). Teaching vocabulary through picture cards in Islamic Elementary School: a case study in Nida Suksa School, Thailand. Jurnal Madrasah, 13(1), 26-38.

Octaberlina, L. R. (2016). Plagiarism in English language theses in Indonesia. Jurnal Ilmu Pendidikan, 14(3).

Octaberlina, L. R., \& Anggarini, I. F. (2020). Teaching vocabulary through picture cards in Islamic Elementary School: a case study in Nida Suksa School, Thailand. Jurnal Madrasah, 13(1), 26-38.

Octaberlina, L. R., Anggarini, I. F., \& Muslimin, A. I. (2020). Virtual English teaching in remote area: a case study. Journal of Critical Reviews, 7(19), 9707-9713.

Amalia, L. L. (2019). REFLECTIVE PRACTICE AND SELF-IDENTITY AS PARTS OF PROFESSIONAL DEVELOPMENT: A SURVEY IN A TERTIARY LEVEL. E-Link Journal, 6(1), 160-163.

Asrifan, A., Zita, C. T., Vargheese, K. J., Syamsu, T., \& Amir, M. (2020). THE EFFECTS OF CALL (COMPUTER ASSISTED LANGUAGE LEARNING) TOWARD THE STUDENTS'ENGLISH ACHIEVEMENT AND ATTITUDE. JOURNAL OF ADVANCED ENGLISH STUDIES, 3(2), 94-106.

Asrifan, A. (2021). ACADEMIC WRITING. LawArXiv. January, 2. https://doi.org/10.31228/osf.io/x2s7e

Asrifan, A. (2020). TUTORIAL PENGGUNAAN QUIZIZZ (www. quizizz. com) PADA PEMBELAJARAN. https://doi.org/10.31219/osf.io/kgnza

Asrifan, A. (2021). Abd Ghofur.". THE USE OF READING CIRCLES IN INCREASING STUDENTS SPEAKING ABILITY AT THE ELEVENTH GRADE SMK NEGERI, 1. https://doi.org/10.31219/osf.io/8vjxy

Asrifan, A. (2020). Pandemic, Humanity and Education. https://doi.org/10.31219/osf.io/q2gpk

Asrifan, A. (2021). USING CAT AND MOUSE GAME TO IMPROVE STUDENT'S SPEAKING ABILITY AT THE ELEVENTH GRADE OF MA YMPI RAPPANG. https://doi.org/10.31219/osf.io/phtvn

Asrifan, A., \& Ghofur, A. (2021). THE USE OF READING CIRCLES IN INCREASING STUDENTS SPEAKING ABILITY AT THE ELEVENTH GRADE SMK NEGERI 1 PANCARIJANG. https://doi.org/10.31219/osf.io/8vjxy

Asrifan, A. (2021). Book Review: Halliday. 1989. Spoken and Written Language. Oxford University Press. https://doi.org/10.31219/osf.io/ej8tb

Asrifan, A., \& Ghofur, A. (2021). TALK, ACTION, SILENCE, INTERRUPTION AND THEIR IMPLICATIONS IN BUGINESE SOCIETY (SOPPENG REGENCY). https://doi.org/10.31219/osf.io/pv3ku

Asrifan, A. (2020). PENILAIAN BERBASIS ANDROID MENGGUNAKAN APLIKASI PLICKERS. https://doi.org/10.31219/osf.io/htreq

Asrifan, Andi, Octaberlina, L. R., \& Agus, Selviana. (2021, January 8). IMPROVING STUDENTS' SPEAKING ABILITY THROUGH SIMULATION OF JOB INTERVIEW. Zenodo. http://doi.org/10.5281/zenodo.4428778 
Andi Asrifan, Like Raskova Octaberlina, \& Eka Safitri. (2021, January 8). THE EFFECTIVENESS OF USING RECITATIVE METHOD TO IMPROVE STUDENTS' VOCABULARY MASTERY. Zenodo. http://doi.org/10.5281/zenodo.4428303 
